\title{
A TANULÁSI SIKERESSÉG ELŐFELTÉTELEINEK DIAGNOSZTIKUS ELEMZÉSI LEHETŐSÉGEI AZ ISKOLA ELŐKÉSZÍTŐ SZAKASZÁBAN
}

\section{Szerző:}

Medovarszki István

Eszterházy Károly Egyetem

Szerző e-mail címe:

medo.istvan@gmail.com

\section{Lektorok:}

Virág Irén $(\mathrm{PhD})$

Eszterházy Károly Egyetem

Zentai Gabriella $(\mathrm{PhD})$

Békéscsabai Tankerületi Központ

...és további két anonim lektor

\section{Absztrakt}

Az általános iskola első osztályának előkészítő szakaszában nagy segítség a pedagógusoknak a fejlesztő munka tervezésében, ha tisztában vannak a tanulóik alapkészségeinek, intelligencia szintjének és kreativitásának fejlettségével. Az egyéni tanulói igényeknek megfelelő, személyre szabott tanítás-tanulás nem képzelhetô el a tanulók alapos diagnosztikus vizsgálata nélkül. Az alábbi cikkben egy komplex tanulói képességprofil felállításának menetét és az alkalmazott tesztek sajátosságait mutatjuk be, valamint az IPOOmodell képességdiagnosztikában való értelmezésének lehetôségét. A kutatásban a békéscsabai Jankay Tibor Két Tanitási Nyelvü Altalános Iskola első évfolyamára beiskolázott három párhuzamos osztály tanulói $(n=66)$ vettek részt, és a képességprofilok felállitása során különböző mérőeszközök összesen tizenhét szubtesztjét alkalmaztuk. A tanulmány első részében a felhasznált tesztekre és azok alkalmazásának indokaira fókuszálunk, a második felében pedig az eredmények összetett statisztikai értelmezésével szeretnénk képet alkotni az egyes részképességek kapcsolatairól is. A komplex tanulói képességprofilok felállítása során a következő teszteket alkalmaztuk: Diagnosztikus fejlödésvizsgáló és kritériumorientált fejlesztő rendszer, Raven szines progresszív mátrixok, Goodenough-rajz̨teszt, Torrance-kreativitástesz̨t körök altesżje, eDia (Szegedi Tudományegyetem Oktatáselméleti Kutatócsoport), Kognitív profil tesžt.

Kulcsszavak: diagnosztikus mérés, általános iskola, előkészítő szakasz, kiemelt figyelmet igénylő tanulók azonosítása, IPOO-modell

Diszciplinák: pedagógia, pszichológia

\begin{abstract}
DLAGNOSTIC CRITERIA FOR ESTABLISHING THE LIKELIHOOD OF SUCCESS AMONGST PUPILS ABOUT TO START SCHOOL

In the primary school at the preparation stage, it is crucial and a basic expectation that all teachers must be aware of and be familiar with the basic skills and the level of creativity of each child that they teach. Without the detailed diagnostic check of each child it is not possible to tailor our lessons to the individuals and a personalized teaching-learning cannot be delivered. In the below article the set up of a complex skill profile and the features of the applied tests can be seen. It also shows the possibility of the IPOO model interpretation in skill diagnostics. In this survey, 66 students participated from the three parallel 1st grade classes from the Jankay Tibor Bilingual Primary School and for setting up their skill profiles 17 subtests of various measuring tools were used. In the first part of the study, the focus is on the tests used and on the
\end{abstract}


reasons and motivations for the choice of the tests. In the second part of the study the focus is on the connections of sub-capacities by the interpretation of the complex statistical results. The following tests were used during the preparation of the complex students' skill profiles: diagnostic development review and criterion-oriented development system, Raven's Coloured Progressive Matrices, Goodenough Drawing test, Torrance Test of Creative Thinking - Circles Subtest, eDia (University of Szeged Theoretical Education Research Group) and Cognitive Profile test.

Keywords: diagnostic measurement, primary school, preparation stage, identifying students who need raised attention, IPOO model

Disciplines: pedagogy, psychology

Medovarszki István (2019): A tanulási sikeresség előfeltételeinek diagnosztikus elemzési lehetőségei az iskola előkészítő szakaszában. OxIPO - interdiszciplináris tudományos folyóirat, 2019/2, 55-68.

doi: 10.35405/OXIPO.2019.2.55

Napjainkban tudományos és laikus körökben is folyamatos diskurzus tárgyát képezi, hogy a nagy nemzetközi tanulói teljesítményméréseken (OECD PISA, TIMSS, PIRLS) a magyar tanulók teljesítménye elmarad a legjobban teljesítő országok tanulóinak eredményeitől. Hazánkban - nemzetközi összehasonlításban is ritkaságnak számító módon - az országos kompetenciamérés keretében minden évben mérik a tanulók matematikai és szövegértés kompetenciáit 6., 8., és 10. évfolyamon. Ezt megelőzően az első osztályos tanulók körében a DIFER mérés azok körében ajánlott, akik az óvodai és tanítói jelzések alapján további segítséget igényelnek az eredményes továbbhaladáshoz. A tanulói teljesítmények nyomon követéséhez és a pedagógiai hozzáadott érték meghatározásához a köznevelési intézményeknek rendelkezniük kell olyan helyi jó gyakorlatokkal és tesztadaptációkkal, melyek támogatják azt, hogy a pedagógiai folyamatok akár a köznevelés teljes időtartama alatt elemezhetővé váljanak. Jelen cikkben az általános iskolába belépő tanulók bemeneti mérésének egy konkrét általános iskolai gyakorlatát fogjuk az eredmények elemzésével együtt bemutatni.

A hazai köznevelési rendszerben a Diagnosztikus fejlődésvizsgáló és kritériumorientált fejlesztő rendszer az első mérés-értékelési eljárás, mellyel a tanulók iskolás éveik alatt találkoznak. Az EMMI a tanév rendjérôl szóló rendeletében határozza meg az általános iskolák teendőit azokkal a tanulókkal kapcsolatban, akik az óvodától kapott tájékoztatás vagy az első osztály elő- készítő szakaszában szerzett tapasztalatok alapján a dinamikus fejlődésük érdekében külön támogatásra szorulnak. A fejlesztés irányának és területeinek kijelöléséhez első lépésként a Diagnosztikus fejlődésvizsgáló rendszert vehetik igénybe, mely minden magyarországi köznevelési intézményben rendelkezésre áll (13/2018. EMMI rendelet 11. \6. bekezdés). A DIFER rendszernek kiterjedt szakirodalma van, a teszt széleskörben ismert és alkalmazott, ́́gy ebben a cikkben csak érintőlegesen kerül bemutatásra. A DIFER alkalmazásával a pedagógusok hasznos információkat szerezhetnek a tanulók alapkészségeinek fejlettségéről, a teszt kiértékelése után pedig hủ képet kapnak arról, hogy a tanulók mely képességterületeken sajátították el és gyakorolták be optimális szinten az eredményes iskolai haladáshoz nélkülözhetetlen elemi készségeket. A DIEFR hét szubtesztje - irásmozgás-koordináció, beszédhanghallás, relációszókincs, elemi számolás, tapasz̨alati következtetés, tapasztalati összefüggés-megértés és szocialitás komplex tükröt mutat a tanulók elemi alapkészségeirôl, mely információk nélkülözhetetlenek az egyéni tanulói igényeknek megfelelő, differenciált tanulási folyamatok megtervezéséhez (Nagy és mtsai, 2004).

Az intelligencia mérése is komoly szakirodalmi háttérrel áll rendelkezésünkre (Caroll, 1993; Lányiné Engelmayer és mtsai, 1996; Mérei és Szakács, 1996). Az intelligencia meghatározására számtalan definíció áll a rendelkezésünkre. Érvényesnek tekinthetjük Sir Francis Galton gondolatait, miszerint az intelligencia az 
érzékelési és észlelési készségek fejlettségét jelenti. A lélektani kutatások intelligenciához kapcsolódó eredményeinek gyarapodása során ennél a meghatározásnál árnyaltabb képet tár elénk Alfred Binet, aki szerint az intelligencia a kognitív képességek és a problémamegoldó képesség fejlettségének mérôje. David Wechsler eredményei alapján az intelligencia egy nagyon összetett képességrendszer, melynek fejlettsége meghatározza azt, hogy az egyén milyen minőségú döntések meghozatalára képes, és a környezetével milyen interakciós kapcsolatokat tud kialakítani. Luis Leon Thurstone kutatásai mutatnak rá, hogy az ideális intelligenciatesztek nem csupán a Charles Spearman által leírt általános intellektuális képességet (g-faktor), vagy az adott egyedi tevékenységek eredményes végrehajtásához szükséges intellektust (s-faktor) mérik, hanem egy általa csoportfaktornak nevezett összetett képességrendszert. Véleménye szerint a csoportfaktort az alábbi hét kognitív képességterület alkotja: šókincs folyékonysága, verbális felfogás, számolás, memória, indukció, térbeli tájékozódás és a felfogás sebessége (Mező, 2016). Számos intelligenciateszt közül válogathatunk a tanulói profilok felállítása során, választásunk a John C. Raven által kidolgozott intelligenciatesztre esett (Raven és mtsai, 2003). A tesztelés lebonyolításában az iskola pszichológusa volt a segítségünkre, mivel az intelligencia teszt felvételéhez és kiértékeléséhez a pedagógusok nem rendelkeznek speciális, szakmai kompetenciákkal.

A Florence Goodenough által kidolgozott emberalak ábrázolás minősítési eljárás alkalmazását követően határozhatjuk meg tanulóink rajzkvóciensét. Ez a rajzteszt a részleterettség, komplexitás, arányok és motoros koordináció területeit méri (Goodenough, 1926). Az IQ és az RQ feltételezett összefüggése ellenére csupán kiegészitő vizsgálatként alkalmaztuk a rajztesztet a kutatás során, nem kívántuk a Raven CPM-et helyettesíteni vele, azonban az IQ-RQ korrelációt mindenképpen vizsgálataink tárgyává kívántuk tenni. A két érték közötti komolyabb eltérés egyéb kognitív vagy pszichés diszfunkció jelenlétét sugallhatja a pedagógusok részére, melynek feltárására intézményen kívüli szakemberek bevonása lehet indokolt (Torda, 1988).

A DIFER teszt kiegészítőjeként alkalmaztuk a Szegedi Tudományegyetem Oktatáselméleti Kutatócsoportjának fejlesztéseként elérhető eDia iskolakeędô méró- csomag online mérési rendszert, mellyel az olvasás elökésaségeit és a korai numerikus késaségek és induktiv gondolkodás fejlettségét vizsgálhattuk. A teszteket számítógépes támogatással vettük fel, figyelembe véve az online mérés-értékeléssel, különösen az eDia rendszerrel kapcsolatos kutatások megállapításait, miszerint az első osztályos tanulóknak nem jelent különösebb nehézséget az infokommunikációs eszközök használata, és ezek alkalmazása során a teszt megbízhatósága megfelelő marad (Molnár, 2015). A tanulókról kapott kép további szélesítése érdekében a szintén online felvehetô Kognitív profil teszt négy résztesztjét - figura teszt, figyelem, képemlékezet, térészlelés - választottuk a tanulók további képességterületeinek feltérképezésére. Az iskolai kudarcok elkerülése érdekében fontos, hogy sokoldalú kép alakuljon ki tanulóinkról, melynek felhasználásával pontos információt kapunk azokról a részképességterületekről, melyek esetlegesen fejletlenebbek, így a tanulók a későbbiekben célzott fejlesztésben részesülhetnek (Gyarmathy, 2009).

\section{Az alkalmazott tesztek ismertetése}

A tesztek és a kapott eredmények leírása előtt néhány gondolatot szánnunk kell az IPOO-modell bemutatásának és szólnunk kell a tanulói képességdiagnosztikában történő értelmezésének lehetőségeiről is. A Mező" Ferenc és Mezó" Katalin által 2007-ben kidolgozott tanuláselmélet a tanulást információfeldolgozásként értelmezi (Mező és Mező, 2007). Az IPOOmodellnek azonosíthatóan kognitív pszichológiai gyökerei vannak. A kognitivista tanuláselmélet szerint a tanulás az emberi elme belső tevékenységének eredménye. E tanuláselmélet az információ mentális folyamatokban történő feldolgozására koncentrál, és arra, hogy a tanulás folyamán hogyan változik meg a gondolkodás és a belső mentális struktúra. Báthory Zoltán írta le a tanítás-tanulási folyamat rendszerszemléletű modelljét, mely modell pedagógiai kibernetikai és pedagógiai rendszerszemléleti előzményekkel bír: „A tanítás-tanulás rendszerszemléletű modellje a bemeneti (input), a folyamat (process) és a kimeneti (output) tényezőket, a környezetet és mindezen komponensek közti információáramlást, információ-visszacsatolást és a kölcsönhatásokat foglalja rendszerbe.” (Báthory, 
1992: 12). Az IPOO-modellben négy fó fázist lehet elkülöníteni, melyek a következők: input (információszerzés), process (az információ feldolgozása), output (az információ felhasználása) és az organizáció (tanulásszervezés). Bár a modell eredetileg tanulásmodellként került kidolgozásra, azonban az IPOO-modellben meghatározott négy szakasz egyéb neveléstudományi vonatkozásban is értelmezhetô. Kutatásunkban a tanulók diagnosztikus vizsgálata volt a cél és az IPOO-modellt adekvát módon alkalmaztuk a tanulói képességprofilok felállításának menete során.

A modell input fázisát a tesztfelvételre, az process fázist a tesztelés során megvalósuló kognitív folyamatokra, az outputot pedig a tesztek eredményeire alkalmaztuk. Organizációnak tekinthető a tesztek kiválasztásának folyamata, a tesztfelvétel környezetének és az alkalmazott eszközöknek a biztosítása. A szervezés körébe tartozik az is, hogy a vizsgálatvezetô ismerje az alkalmazni kívánt eljárások sajátosságait, illetve, hogy tisztában legyen azzal, hogy milyen kognitív területek, tanulási részképességek elemezhetôk az adott vizsgálati eljárással. A tanulmány következő egységében az input fázisra, azaz az alkalmazott tesztek sajátosságaira fókuszálunk.

\section{A diagnosztikus fejlódésvizsgáló rendszer}

Az általános iskolába belépő gyermekek nagyon sokszínủ személyiségjegyekkel és még eltérőbb készségképesség fejlettséggel, kognitív és affektív érettséggel kezdik meg általános iskolai tanulmányaikat. Egyes képességterületeken akár több éves különbségek is mutatkozhatnak egy adott évfolyam tanulói között (Józsa, 2004; Nagy, 2000). Ezen képességkülönbségek diagnosztikus azonosítására dolgozta ki 1975-ben Nagy József a Preventív Fejlettségvizsgáló Rendszert, melynek két résztesztje a tudás és a magatartás komponenseit mérte. A PREFER továbbfejlesztett változata lett 2004-ben a Diagnosztikus fejlődésvizsgáló és kritériumorientált fejlesztő rendszer, mely az iskolai tanulás során kiemelten fontos részképességeket mérte. A teszt hét szubtesztet tartalmaz, melyek felvétele során a pedagógusok teljes képet kaphatnak a tanulók elemi alapkészségeiről. Jelentősége abban áll, hogy a fejlesztés célzottan lesz megvalósítható az egyéni differenciálás során. A DIFER által vizsgált hét alapkészség a kö- vetkező: írásmozgás-koordináció, beszédhanghallás, relációszókincs, elemi számolás, tapasztalati következtetés, tapasztalati összefüggés-megértés és a szocialitás. A programcsomag a kiértékelést követően arról ad információt, hogy a tanulók az elemi alapkészségek elsajátításának mely szintjén állnak. Ennek meghatározásához öt szintet határoz meg: előkészítő, kezdő, haladó, befejezô és optimum (Nagy és mtsai, 2004). Az iskolai fejlesztés célja így az, hogy minden tanuló eljusson az optimális elsajátítás szintjére, mely nélkülözhetetlen az iskolai sikerességhez. Mivel minden tanuló eltérő képességprofillal rendelkezik, így fejlesztésük is csak az egyéni igényeiknek történő megfelelés elvének alkalmazásával lehet eredményes.

\section{Raven szines progressziv mátrixok}

Az intelligenciakutatás története során számos eltérō és egymásnak ellentmondó elemzést és következtetést fedezhetünk fel az emberi intellektus definiálása során. Az intelligenciával foglalkozó kutatók két nagy csoportba sorolhatók az intelligencia természetét illetően vallott nézeteik alapján: szingularisták és a pluralisták. A szingularista paradigma szerint az intelligencia a részképességek elemeiből áll össze, és egységes rendszerként meghatározza egyéb szellemi képességeinket is. A szingularisták szemlélete szerint az általános intelligenciát meghatározó faktort nevezzük g-faktornak, mely többé-kevésbé egységes mérője az intellektusnak. Ennek értelmében amennyiben a vizsgált személy egy adott tevékenységben jól teljesít, úgy nagy valószínűséggel egy másik területen is hasonló eredményt fog elérni. A pluralisták s-faktornak nevezett speciális faktorokat határoznak meg, melyek determinálják, hogy különböző feladatokban hogyan teljesít az egyén, és ezek a faktorok egyedi tevékenységekben manifesztálódnak. A pluralista intelligenciafelfogás szerint az intelligencia egy nagyon összetett, bonyolult rendszer, az intellektuális képességek egymástól elkülönülnek és függetlenül érvényesülnek. A pluralista felfogás jellemző példája a Howard Gardner által leírt intelligenciamodell, mely nyolc olyan területet határoz meg, melyekben minden egyén elér egy bizonyos szintet, azonban ezen szintek fejlettsége minden személy esetében eltérő minőségű. A gardneri intelligenciafelfogás szerint megkülönböztethetők nyelvi-verbális, logikai-matematikai, 
térbeli-vizuális, zenei, testi-kinesztetikus, interperszonális, intraperszonális és természeti képességek (Gardner, 1999).

A John C. Raven által kidolgozott színes intelligenciateszt használatának leírása szerint ,A faktoranalitikus vizsgálatok kimutatták, hogy a általános értelem leginkább az. észlelési, nem verbális relációk kibontásán és felhasználásán alapuló problémák eredményével vág egybe.” A színes progresszív mátrixok teszt a 6-11 éves tanulók körében alkalmazható eredményesen, és erős korrelációt mutat az életben elért eredményekkel és sikerességgel. A gyermekek számára készített színes változat háromszor (A, AB, B csoport) 12 darab matricát tartalmaz. Minden egyes táblán egy-egy matrica található, melyből hiányzik egy terület. A vizsgált személynek fel kell ismernie a vízszintes és a függőleges irányú mintázatok rendezőelvét, és ennek megfelelőek kell kiválasztania a hat lehetséges válaszból a megfelelőt. Az első 12 tesztfeladat homogén matricákat tartalmaz, az $\mathrm{AB}$ és $\mathrm{B}$ csoportok matricái négy egységet mutatnak, melyek közül az egyik hiányzik. E két csoport első négy-négy feladatában a négy kisebb matrica azonos, a további feladatokban a négy ábra egy egységet alkot. A színes Raven-teszt népszerűsége abban rejlik, hogy perceptív tesztként a verbális képességeket nem méri, így kultúrafüggetlen és a szociális vagy társadalmi háttér sem befolyásolja az eredményeket. Ezen kívül jelentős előnye az, hogy viszonylag gyorsan felvehető és a kiértékelése is pillanatok alatt elvégezhető. Egyszerű felépítése és a verbalitás mellőzése miatt könnyedén adaptálható lenne számítógépes környezetbe is, így egyidőben egy adott tanulócsoport több tagja is részt vehetne a vizsgálatokban. Nagy hátránya, hogy hazánkban intelligencia tesztet csak pszichológus végzettséggel rendelkező szakember vehet fel, így ez az iskolai környezetben történő alkalmazását erősen korlátozza.

\section{Goodenough emberalak-rajz elemzés módsz̨ere}

A gyermekek intelligenciájának egy másik irányú vizsgálatára ad lehetőséget a Florence Goodenough által kidolgozott emberalak-ábrázolási elemző módszer. Az emberi test alakja, sajátosságai és anatómiai szabályosságai kiemelt figyelmet kapnak a gyermekek egyéni fejlődése során. Az emberrajzok a gyermeki alkotómunkák egyik legkorábban megjelenő és leggyakrabban visszatérő motívumai, az egyszerű firkáktól az összetett és komplex művekig bezárólag. Az emberi test élethű ábrázolásához a gyermekeknek fejlett módon kell érzékelniük az őket körülvevő teret, tisztában kell lenniük az irányokkal és a testsémákkal (Torda és Darvas, 2001). A gyermekek kognitív fejlődésével párhuzamosan az emberábrázolásuk színvonala is fejlődik, így a rajzok elemzését követően megkapott rajzkvóciensből következtethetünk az általános intelligencia fejlettségére is. Az IQ és az RQ nagymértékű eltérése a pszichés fejlődés zavarára utalhat, mely diagnózis további elemzéseket, vizsgálatokat és terápiát tehet szükségessé. A teszt egyik nagy előnye, hogy nem veszi figyelembe az eltérô háttérből származó különbségeket, mivel az emberi test ábrázolása és anatómiai szabályosságának felismerése határozottan kultúraindependenciát mutat. A teszt 3-13 éves kor között alkalmazható, felvétele és kiértékelése is gyors és egyszerű. A Goodenough-rajzteszt elemzése során az ábrázolásokat két csoportba sorolhatjuk. Az , $A$ ” csoportba kerülnek a nem felismerhető firkálások, míg a „B” csoport tagjai egyértelműen emberalakként értékelhetők. A rajzokat négy szempont mentén, szigorúan meghatározott feltételek megléte alapján kell értékelni. A teszt vizsgálja a rajzok részletezettségét, komplexitását, az arányokat és a motoros koordináció fejlettségét. A rajzok elemzése során összesen 46 pont adható, melyek öszszesítését követően meghatározható a rajzkor, ahol a Goodenough által kidolgozott rendszer alapján minden pont három hónapnyi fejlődésnek feleltethető meg. A valós életkor és a rajzkor ismeretével már könnyedén kiszámítható a rajzkvóciens is.

\section{A kereativitás vizsgálata Torrance-körök segitségével}

Az intelligenciatesztek a kognitív képességeknek csak egy szűkebb szeletét képesek mérni, ugyanis ezen tesztek többsége a konvergens gondolkodás elemzését teszik csupán lehetôvé. A konvergens gondolkodás során a vizsgált személy egy adott probléma egyoldalú megoldására fókuszál, ezen tevékenységében meghatározott mintázatokat és szabályosságokat kell felismernie, és többnyire előre meghatározott választási lehetőségekből kell megtalálnia a helyes megoldásokat. Ezzel szemben a divergens gondolkodás egy összetettebb kognitív folyamat, mely során az adott probléma több ol- 
dalról történő vizsgálatára, és egyedi megoldások megtalálására van szükség, jellemzően nyílt végű feladatokon keresztül. Fontos kiemelnünk, hogy a divergens problémamegoldás során az adott problémának több, egyedi megoldása lehetséges. A divergens gondolkodás - így a kreativitás - minősége megmutatkozik a fluencia, a flexibilitás, az originalitás és a komplexitás mutatóiban. Így a kreativitásra mint az intelligencia kiegészítőjére tekinthetünk, arra a tevékenységre, melynek fố célja az értékteremtés, az alkotás és az újitás. Ellis Paul Torrance dolgozta ki a Torrance Test of Creative Thinking (TTCT) elnevezésû kreativitás tesztet. E teszt egyik eleme a körök teszt, ahol a vizsgált személynek egy üres köröket tartalmazó lapon kell kiegészítenie a köröket úgy, hogy azok az új ábrák fontos részét képezzék. Ez az alteszt a vizuális kreativitást méri, így a verbális képességek fejletlenségéből, és a kulturális különbségekből fakadó hátrányok nem befolyásolják a teszteredményeket. A tesztfelvétel gyors, minden tanulónak 20 perc áll a rendelkezésére a feladatok végrehajtására, és a tesztek kiértékelése is viszonylag egyszerú, azonban megjelenhet benne az értékelést végző személy szubjektuma. A körök teszt értékelése során külön pontokat kap a fluencia (a rajzok száma), a flexibilitás (az adott tárgykörbe besorolható rajzok száma), az originalitás (az adott tanulócsoportban csak nála megtalálható rajzok száma) és a komplexitás (több kör felhasználásával készített rajzok száma). Főként a teszt originalitás mutatója jelzi számunkra, hogy a vizsgált személy mennyire képes egy adott problémával kapcsolatban egyedi, csak rá jellemző megoldásokat adni. Az originalitás vizsgálatával képet kaphatunk arról, hogy tanulóink mennyire képesek az egyedi gondolkodásra, azonban az originalitás pontszáma függhet a fluenciától: azaz minél több választ ad a tanuló, valószínúleg annál magasabb originalitás értéket is mérünk majd nála (Mező és Mező, 2017).

\section{eDia iskolakezdó mérócsomag}

Napjaink iskolája hajlamos azt feltételezni a tanulókról, hogy tudásuk és értelmi-érzelmi fejlődésük szempontjából homogén csoportot alkotnak, és ennek megfelelően szervezi az iskolai tevékenységeket, nincs különbség a tananyag tartalmában, a tanulási folyamatok megszervezésében és a tanítás-tanulásra fordított idő- ben sem. Mindenkinek ugyanazt, ugyanakkor és ugyanúgy akarja megtanítani, ami a tanulásról vallott modern felfogások szerint nem lehet hatékony (Molnár, 2015). Az egyéni differenciálás és készségképességfejlesztés megszervezéséhez nélkülözhetetlen, hogy tanulóink előzetes tudását, képességeiknek aktuális fejlettségét pontosan ismerjük. Az elemi alapkészségek (írás, olvasás, számolás) kialakítása és fejlesztése során szükséges tudnunk, hogy mi az az alap, melyre tanórai gyakorlatunkat felépíthetjük. Az általános iskola alapozó szakaszát kezdő gyermekek alapkészségeiben szignifikáns különbségek lehetnek, egyes képességterületeken ezek a fejlettségben tapasztalható eltérések akár több évet is jelenthetnek. A Szegedi Tudományegyetem Oktatáselméleti Kutatócsoportja által kifejlesztett eDia (Elektronikus diagnosztikus mérési rendszer) iskolakezdő mérócsomag az olvasás előkészségeit illetve a korai számolási készséget és az induktív gondolkodást méri. A tesztek online formában teljesíthetők, csoportosan, egyszerre több tanulót vonhatunk be a vizsgálatba. A teszt felvétele viszonylag gyors, a teljes tesztelés három tanóra alatt megvalósítható, a kiértékelést a program végzi. Felmerülhet, hogy az eredmények az IKT használatából fakadóan torzulnak, azonban ennek veszélyét egy megelőző gyakorlással kompenzálni lehet, ahol a tanulók az egér használatát játékos formában begyakorolhatják. A programcsomag nagy előnye például a DIFER-rel szemben, hogy a tesztet felvevő személy szubjektivitása nem befolyásolja az eredményt. Az olvasás előkészségei közül hatékonyan méri a fonológiai tudatosságot, a fonológiai egységekhez való hozzáférési képességet, a fonémák azonosításának és azok megkülönböztetésének képességét, illetve a hangokkal, szótagokkal végzett múveletek készségét. A matematikai tudás mérése során vizsgálja az elemi számlálást, a múveletvégzést, a mennyiségrelációk értelmezését, és a mennyiségek és számok összekapcsolásának képességét. Az induktív gondolkodás során a vizsgált személynek megadott minták alapján kell szabályokat alkotnia, és a felállított szabály alapján további feladatokat megoldania. Az induktív gondolkodás fejlettsége meghatározhatja az iskolai sikerességet, és alapjául szolgál más kognitív területek fejlődéséhez, ilyen például az intelligencia, a problémamegoldó képesség vagy az adaptív tanulás. 


\section{Kognitiv profil teszt}

A tanulási sikeresség alapfeltétele, hogy a tanulók olyan biztos és megfelelően fejlett alapkészségekkel rendelkezzenek az iskolába lépés időpontjában, melyek lehetővé teszik azt, hogy az iskolai tananyag elsajátítása során végzett tevékenységeikben hatékonyak és eredményesek legyenek. A problémamentes tanulás vagy a konstruktivista tanuláselmélet által értelmezett fogalmi váltások, valamint a tananyaggal és a tanuló környezetével való pozitív interakciós kapcsolat kialakítása nem képzelhető el a tanulási alapkészségek megfelelő fejlettsége nélkül. A Kognitív profil teszt azokat a tanulási alapkészségeket vizsgálja, melyek a tanítás-tanulás folyamatában a gyermekek eredményességét determinálják. A teszt alapját az International Cognitive Profil Test képezi, mely a diszlexia megjelenési jegyeit vizsgálta. A teszt magyar adaptációja Gyarmatby Éva nevéhez füződik, aki a tesztet magyar nyelvűre és a hazai tanulói populáció sajátosságaira alakította át (Smythe, 2002; Gyarmathy, 2009). A teszt több alteszttel rendelkezik, melyek az információfeldolgozás képességét és az iskolai alapkészségeket elemzik. Gyarmathy felfogása szerint az 5-7 éves korosztály még nem rendelkezik azzal az előzetes tudással, mely lehetôvé teszi azt, hogy az IKT támogatott diagnosztika eszközrendszerét használják. Ezért vagy szinkron-kontakt tesztfelvételre van szükség, vagy a vizsgálatvezető kiválogathatja azokat a feladatokat, melyekkel online környezetben is eredményesen mérhetôk ebben a korban a részképességek. Mivel az első osztályos gyerekek a 6-7 éves populáció tagjai, így a második lehetőséget választottuk és gondos mérlegelés után a tesztrendszer négy altesztjét választottuk ki. A Kognitív profil teszt alkalmazásával így a tanulók figurális absztrakciós képességét, koncentrációs képességét, térészlelését elemeztük, valamint az emlékezet, szeekvencialitás és szimultán megjegyzés területeiről is teljes képet alkothattunk. A figyelem tesztet papír alapon végeztük el, ugyanis az online tesztben identifikálandó betűpárokat a gyerekek az egér használatával az első kísérletre nehezen jelölték meg.

\section{Kérdések}

Kutatásunkban arra kerestük a választ, hogy melyek azok a konkrét teszt és tesztfelvételi eljárások, melyek alkalmazásával az általános iskola előkészítő szakaszában a legteljesebb képet alkothatjuk az iskolába belépő első osztályos tanulókról. Fontosnak tartjuk, hogy minden gyermekről komplex képességprofillal rendelkezzünk, és lehetőségünk legyen arra, hogy későbbi mérések eredményeivel való összehasonlítással valid képet kapjunk a tanulók fejlődéséről is. Figyelembe vettük az oktatásirányítók és a tudományos élet képviselőinek ajánlásait is, törekedtünk a tanulói részképességek teljes feltárására. Helyi pedagógiai jó gyakorlatunk kialakítása során arra a kérdésre is kerestük a választ, hogy mik azok a mérési metódusok, melyek komplex módon feltárják saját tanulóink elemi alapkészségeit.

\section{Minta}

A vizsgálatban a 2018-2019-es tanévben a békéscsabai Jankay Tibor Két Tanítási Nyelvú Általános Iskola első évfolyamára beiskolázott három osztály tanulói vettek részt $(n=66)$. A bemutatott tesztek együttes alkalmazása pilot vizsgálat volt intézményünkben, mely a későbbi helyi gyakorlatunk kialakításának alapját képezi. A minta alacsony elemszáma miatt azonban csak korlátozott következtetések levonására volt lehetőségünk. A résztvevő tanulók közül 36 lány (54,5\%) és 30 $(45,5 \%)$ fiú. Bár a vizsgálat időpontjában mindannyian első osztályosok voltak, érdemes különös figyelmet szentelni az életkoruk elemzésére is (lásd: 1. és 2. táblázat). Az életkori adatokból megfigyelhetô, hogy a tanulók iskolakezdési idôpontjában nem érvényesül az az oktatáspolitikai cél, hogy a hatodik életévüket betöltő gyerekek iskolába menjenek. Sőt, az ebben a tanévben iskolát kezdô tanulók átlagosan már majdnem hét évesen $\left(M_{\text {kor }}=6\right.$ év és 11,85 hó) kerültek az iskolapadokba.

Amennyiben nem vizsgálnánk a tanulók egyéni képességeinek eltéréseit, már az életkori mutatókból is egyértelmúen fel kellene fedeznünk azt, hogy a gyerekek között hatalmas eltérések tapasztalhatók, nem képeznek homogén csoportot, így a tanítás-tanulási folyamatokban erősen meg kell jelenjenek az adaptív és személyre szabott tanulást támogató differenciált tanulásszervezési megoldásoknak. 
1. táblázat: A bevont tanulók életkori mutatói (forrás: a Szerzó)

\begin{tabular}{l|l|l|l|l|l|l|l} 
Változó & Átlag & Medián & Módusz & Szórás & Variancia & Min. & Max. \\
\hline $\begin{array}{l}\text { A tanulók } \\
\text { életkora (év, hó) }\end{array}$ & $\begin{array}{l}6 e ́ v \\
11,85 \text { hó }\end{array}$ & $7 e ́ v$ & $7 e ́ v$ & 4,24 bó & $\begin{array}{l}1 \text { év } \\
6,007 \text { bó }\end{array}$ & $\begin{array}{l}6 \text { év } \\
1 \text { hó }\end{array}$ & $\begin{array}{l}7 \text { év } \\
9 o^{\prime}\end{array}$
\end{tabular}

2. táblázat: Életkori gyakoriságok (forrás: a Sžerzó)

\begin{tabular}{|c|c|c|c|c|c|c|c|c|c|c|c|c|c|c|c|c|c|c|c|}
\hline \multicolumn{2}{|l|}{ Év } & \multicolumn{9}{|c|}{6 év } & \multicolumn{9}{|c|}{7 év } \\
\hline Hónap & 1 & 3 & 4 & 5 & 6 & 7 & 8 & 9 & 10 & 11 & 0 & 1 & 2 & 3 & 4 & 5 & 6 & 7 & 9 \\
\hline $\begin{array}{l}\text { Előfor- } \\
\text { dulás }\end{array}$ & 1 & 1 & 1 & 3 & 1 & 3 & 5 & 6 & 1 & 2 & 11 & 10 & 7 & 1 & 4 & 1 & 4 & 3 & 1 \\
\hline $\begin{array}{l}\text { Relatív } \\
\text { gyakori- } \\
\text { ság }\end{array}$ & 1,5 & 1,5 & 1,5 & 4,5 & 1,5 & 4,5 & 7,6 & 9,1 & 1,5 & 3,0 & 16,7 & 15,2 & 10,6 & 1,5 & 6,1 & 1,5 & 6,1 & 4,5 & 1,5 \\
\hline $\begin{array}{l}\text { Kumulált } \\
\text { gyakori- } \\
\text { ság }\end{array}$ & 1,5 & 3,0 & 4,5 & 9,1 & 10,6 & 15,2 & 22,7 & 31,8 & 33,3 & 36,4 & 53,0 & 68,2 & 78,8 & 80,3 & 86,4 & 87,9 & 93,9 & 98,5 & 10,0 \\
\hline
\end{tabular}

\section{Az adatfelvétel körülményei}

Az eszközök ismertetésekor nem törekszünk a teljes leírásra, ugyanis az alkalmazott tesztek igen széles szakirodalommal rendelkeznek, és a köznevelési gyakorlatban elérhetôk és használhatók. A tesztek kiválogatásakor fontos szempont volt, hogy minimális időfelhasználás mellett a lehető legtöbb információt öszszegyüjthessük tanulóinkról (lásd: 3. táblázat). A diagnosztikus mérések IPOO-modellben történő értelmezésekor a tesztek felvétele és a tesztfelvételek időpontjának megszervezése, a szükséges eszközök rendelkezésre bocsátása, a számítógépes és online erőforrások és applikációk biztosítása az organizáció fázisában jelentek meg.

A DIFER felvétele egyéni vizsgálat keretében zajlott, és igazodott az útmutató előírásaihoz. A kiértékelés a megadott sztenderdeket követte, minden tanuló esetében azonos volt. Csoportosan, papír alapon, a tradicionális tesztfelvételi módszereket követve rögzítettük a Torrance-köröket és a Goodenough-rajztesztet. E tesztek kiértékelése tanulónként külön-külön történt, azonban enyhe mértékben, de érvényesülhetett a vizsgálatvezetô szubjektivitása. A további tesztek (eDia, Kognitív profil teszt) IKT-támogatással, több esetben online környezetben kerültek felvételre. Felmerült a digitális technikák alkalmazásából származó torzítás veszélye, azonban a tesztfolyamat során azt tapasztal- tuk, hogy a tanulók számára nem jelentett különösebb nehézséget a digitális eszközök használata. Az a tény, hogy az online és a papír alapú tesztfelvétel közel azonos eredményeket ad, és hogy az informatikai kompetenciák fejlettsége nincs szignifikáns hatással az eredményekre, más kutatások eredményeivel vágott egybe (Powers és O’Neill, 1993, Molnár, 2015). Ennek biztosítása érdekében a tesztsorozat elsô lépéseként megismerkedtettük a gyermekeket az új technológiák használatának alapvetô, és az eredményes teszteléshez nélkülözhetetlen elemi ismereteivel. Az online vagy digitálisan támogatott tanulói diagnosztika során a kockázatok mellett az elónyös oldal egyik domináns eleme az, hogy az értékelés független a kiértékelő személyétől.

A DIFER rögzítésekor a tanulók egyénileg jelentek meg a vizsgálati teremben, a tesztszituáció indítása során minden esetben motivációs, bátorító beszélgetésre került sor, melynek célja az oldott, bizalomteli hangulat és légkör megteremtése volt. Minden tanuló esetében nagyjából 35-55 percet vett igénybe a teszt felvétele. A tesztelésre a délelőtti négy tanóra keretében került sor, ezekben az órákban a tanulók még kellóen frissek és könnyebben motiválhatók voltak.

Csoportosan, papír-ceruza alapon rögzítettük a kreativitás (Torrance-körök), a figyelem (Kognitív profil teszt) és az Goodenough-féle emberalak ábrázolási feladatokat. A tanulók így egyszerre, viszonylag időtaka- 
rékos módon voltak képesek kitölteni a feladatlapokat. A Torrance-körök feladatban a tanulók 20 percig tevékenykedhettek, mindhárom tanulócsoportban ugyanazokat az instrukciókat kapták, és a kiértékelést is egy személy végezte. A figyelem tesztre egységesen két perc volt a rendelkezésre álló idő, ennyi idő alatt kellett megtalálniuk egy 33x13-as betûmátrixból az AA és FF betúpárokat. A rajzteszt feladatnál egy A4 méretú rajzlapra készítettek el egy emberalak rajzot, a vizsgálatvezető annyit kért, hogy olyan szép rajzot készítsenek, amilyet csak tudnak. Az egymással összehasonlítható eredmények biztosítása érdekében ezeket a rajzokat is egyazon személy elemezte szigorú szabályokhoz igazodva.

Szintén csoportosan (12-14 fö per alkalom), de individuális, online környezetben teljesítették a tanulók az eDia és a Kognitív profil tesztet. Az online tesztelés előnye volt, hogy a tanulók egyszerre többen dolgozhattak, és a tesztek kiértékelése is gyorsan megtörtént, az eredmények digitális formában voltak hozzáférhetők. Ezen tesztekre is a tanítási napok délelőtti felében került sor, a tanulók digitális környezetben végezték tevékenységeiket. Biztosított volt, hogy önállóan és elmélyülten dolgozhassanak, a zavaró tényezőket kiküszöböltük, így a tanulók figyelme koncentrált és fókuszált tudott maradni. Az eDia feladatsoraira tanulónként két tanitási órát kellett felhasználnunk (a játékos számítógéphasználati órán túl), további egy tanóra szükségeltetett a Kognitív profil teszt lebonyolítására.
Az eDia feladatsorokban a tanulók a szoftver által kapott instrukciók alapján dolgoztak, emiatt a tanulóknak headset-eket kellett biztosítanunk. A kognitív profil teszt megoldása során a tanulók a vizsgálatvezetô személy előzetes utasításait követték.

A tanulók diagnosztikus mérése szerepelt az intézmény tanév rendjéről szóló nevelőtestületi döntésében, a vizsgálat végrehajtását pedagógiai konszenzus övezte. Az első osztályokban tanító pedagógusok tájékoztatást kaptak a vizsgálat időbeosztásáról és a tesztek sajátosságairól. A tanév eleji szülői értekezleteken a szülóket is tájékoztattuk a bemeneti méréseket illetően, akik hozzájáruló nyilatkozat kitöltésével járultak hozzá a vizsgálatokhoz. A vizsgálatok menetét előre rögzítettük, szeptember és október hónapokban pontos menetrend szerint dolgoztunk.

A tesztek felvétele az alábbi sorrendben történt:

- DIFER

- Raven CPM

- Torrance-körök

- eDia olvasás előkészségei

- eDia korai numerikus készségek és induktív gondolkodás

- Emberalak ábrázolás

- Kognitív profil teszt

$\mathrm{Az}$ eredmények matematikai statisztikai elemzését IBM SPSS Statistics v23 szoftver alkalmazásával végeztük el.

3. táblázat: A tesztek felvételére forditott idö (forrás: a Szerző)

\begin{tabular}{|c|c|c|c|}
\hline Teszt & $\begin{array}{l}\text { Egyéni (E) vagy Csoportos (Cs) } \\
\text { tesztfelvétel }\end{array}$ & $\begin{array}{l}\text { Tesztfelvétel időtar- } \\
\text { tama }\end{array}$ & $\begin{array}{l}\text { Kiértékelés időtar- } \\
\text { tama }\end{array}$ \\
\hline DIFER & $\mathrm{E}$ & $35-55$ perc & vizsgálat közben \\
\hline Goodenough-rajzteszt & Cs & 30 perc & $\begin{array}{l}\text { tanulónként } 5-8 \\
\text { perc }\end{array}$ \\
\hline Torrance-körök & Cs & 20 perc & $\begin{array}{l}\text { tanulónként } 15-20 \\
\text { perc }\end{array}$ \\
\hline eDia olvasás előkészsgei & Cs & $25-40$ perc & \\
\hline $\begin{array}{l}\text { eDia korai numerikus készségek és in- } \\
\text { duktív gondolkodás }\end{array}$ & Cs & $30-45$ perc & $\begin{array}{l}\text { digitalisan } 24 \text { oran } \\
\text { belül }\end{array}$ \\
\hline Kognitív profil teszt - figyelem teszt & Cs & 10 perc & $\begin{array}{l}\text { tanulónként } 1-2 \\
\text { perc }\end{array}$ \\
\hline Kognitív profil teszt - figura teszt & Cs & \multirow{3}{*}{$25-35$ perc } & \multirow{3}{*}{ digitálisan azonnal } \\
\hline Kognitív profil teszt - képemlékezet & Cs & & \\
\hline Kognitív profil teszt - térészlelés & $\mathrm{Cs}$ & & \\
\hline
\end{tabular}




\section{Eredmények}

Az IPOO-modell értelmében a következő tematikai egységben a process fázist követő outputokat, azaz a tesztek eredményeit elemezzük. A tesztekhez kapcsolódó alapstatisztikát a 4. táblázat mutatja. Azt már korábban megfogalmaztuk, hogy az intézményünkben első osztályt kezdő tanulók vizsgált mintájában komoly eltérések tapasztalhatók: a legfiatalabb és a legidősebb tanuló között húsz hónapos különbség figyelhető meg. Iskolai tevékenységeink során gyakran vélünk felfedezni összefüggéseket a tanulók életkora és a diag- nosztikus teszteken elért eredményeik, valamint iskolai teljesítményük között. Az elemzést követően azonban kijelenthetjük, hogy nem figyelhető meg összefüggés a teszteredmények és az életkor között (lásd. 5. táblázat). Ezért a pedagógiai gyakorlatban a differenciálás alapját nem képezheti az első osztályos tanulók életkor szempontjából történő homogén csoportokba sorolása (lásd. 6. táblázat). Az iskolaérett tanulók esetében a tanulási részképességek fejlettségében ugyanis nem figyelhető meg olyan minőségi különbözőség, mely az életkorukból következne.

4. táblázat: A tesztekhez kapcsolódó alapstatisztika (forrás: a Szuerōó)

\begin{tabular}{l|r|r|r|r|r|r|r|r|r} 
& $I Q$ & $R Q$ & $\begin{array}{r}\text { eDia } \\
(\text { olv. })\end{array}$ & $\begin{array}{r}\text { eDia } \\
(\text { mat. })\end{array}$ & Figura & Figyelem & Képemlékezzet & Térészlelés & DIFER \\
\hline Átlag & 94,77 & 104.96 & 54.96 & 62.67 & 8.73 & 5.42 & 9.86 & 3.26 & 75.40 \\
\cline { 2 - 11 } Medián & 93 & 104.5 & 55 & 62.20 & 9 & 5 & 10 & 3 & 75.25 \\
\hline Módusz & 91 & 94 & 50 & 51.94 & 8 & 6 & 10 & 3 & 75 \\
\hline Szórás & 9.85 & 14.39 & 19.86 & 16.59 & 2.35 & 2.56 & 4.20 & 1.10 & 10.10 \\
\hline Variancia & 96.92 & 207.05 & 394.4 & 275.06 & 5.52 & 6.56 & 17.63 & 1.20 & 101.99 \\
\hline Minimum & 79 & 77 & 0 & 9.38 & 2 & 1 & 0 & 1 & 55.39 \\
\hline Maximum & 130 & 141 & 100 & 96.88 & 14 & 10 & 20 & 6 & 93.63
\end{tabular}

5. táblázat: Az életkor korrelációi a teszteredményekkel (forrás: a Sẓerző́)

\begin{tabular}{|c|c|c|c|c|c|c|c|c|c|}
\hline Változó & $I Q$ & $R Q$ & eDia (olv.) & $\begin{array}{l}e \text { Dia } \\
\text { (mat.) }\end{array}$ & Figura & Figyelem & Képemlékeret & Térészlelés & DIFER \\
\hline $\mathrm{r}^{*}$ & $-0,015$ & 0,042 & $-0,057$ & 0,030 & $-0,125$ & 0,142 & $-0,139$ & 0,136 & $-0,049$ \\
\hline
\end{tabular}

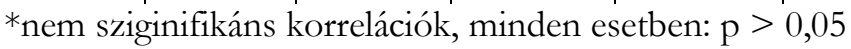

6. táblázat: A legfiatalabb és a legidösebb tanuló eredményei (forrás: a Szerzố)

\begin{tabular}{l|r|r|r|r|r|r|r|r|r} 
Tanuló & IQ & RQ & $\begin{array}{r}\text { eDia } \\
\text { (olv.) }\end{array}$ & $\begin{array}{r}\text { eDia } \\
\text { (mat.) }\end{array}$ & Figura & Figyelem & Képemlékezęt & Térészlelés & DIFER \\
\hline Legfiatalabb & 110 & 127 & 66,67 & 77,16 & 13 & 7 & 13 & 3 & 87,25 \\
\hline Legidősebb & 95 & 121 & 46,67 & 74,70 & 11 & 9 & 10 & 5 & 75,98
\end{tabular}

Láthatjuk, hogy a tanulók életkorának és részképességeik fejlettségének együttjárása nem volt igazolható. Vizsgálatunk következő részében arra kerestük a választ, hogy a tanulók nemverbális tesztben mért intelli- genciája és az emberalak-rajz elemzése után kapott RQ érték mutat-e korrelációt. A pedagógiai közbeszédben jelentős annak a vélekedésnek a túlsúlya, mely szerint az intelligenciahányados és a rajzkvóciens között kimu- 
tatható összefüggés van. Amennyiben a két eredmény között jelentôs a különbség, úgy az valamilyen pszichés diszfunkció jelenlétére utalhat. A kutatásba bevont tanulók esetében ezt nem tudtuk igazolni, ugyanis az IQ és az RQ között alacsony korrelációs együtthatót mértünk $(r=.289 ; p<.020$, további korrelációkat lásd: 7. táblázat). Mindezek ellenére az iskolai gyakorlatban különleges helyet kell szánnunk az intelligencia mérésének, ugyanis a korai tehetségazonosítás során árulkodó jel lehet egy-egy tanuló kiugróan magas intel- ligenciaszintje. Továbbá a magas intelligencia melletti tanulmányi alulteljesítés is erōteljes jelzés lehet a tehetségek azonosítása során. Az intézményesült oktatásban meg kell teremteni annak a személyi feltételeit, hogy rendelkezésre álljanak azok a szakemberek (pl.: teljes állásban foglalkoztatott iskolapszichológus), akik az intelligencia mérésében segítséget nyújthatnak. Amenynyiben erre nincs lehetőség, az iskoláknak kell olyan külső partneri együttműködéseket megvalósítaniuk, melyek ennek a célnak a teljesülését szolgálják.

7. táblázat: Korrelációk a raven CPm IQ és a teszteredmények között (forrás: a Szerzö)

\begin{tabular}{l|r|r|r|r|r|r} 
Változó & $\begin{array}{r}e \text { Dia } \\
(\text { olv. }\end{array}$ & $\begin{array}{r}\text { eDia } \\
(\text { mat. })\end{array}$ & Figura & Figyelem & Képemlékezzet & Térészlelés \\
\hline $\mathrm{r}$ & 0,217 & $0,392^{*}$ & $0,294^{*}$ & 0,172 & $0,256^{*}$ & 0,169 \\
$*_{\mathrm{p}} \leq 0,05$ & & & &
\end{tabular}

Az elemzés további szakaszában olyan teszteket hasonlítottunk össze, melyek hasonló részképességterületeket mérnek, és a kutatás megkezdése előtt feltételeztük, hogy a tanulóink ezeken a teszteken hasonló eredményekkel teljesítenek. Választásunk elóször az eDia rendszer olvasás előkészségei tesztjének fonémaazonosítás és fonémamúveletek altesztjére, valamint a DIFER beszédhanghallás szubtesztjének eredményeire esett. Mindhárom esetben beszédhangokkal kellett a tanulóknak múveleteket végezniük, e teszteknél az auditív észlelés fejlettsége meghatározza a kapott eredményeket. Méréseink azonban nem igazolták a három altesztben nyújtott teljesítmények együttjárását, csupán közepes vagy annál alacsonyabb korreláció volt kiolvasható a statisztikai elemzés eredményeiből. Sőt a 0,5-nél magasabb korrelációs együttható is csak a fonémaazonosítás és a fonémamûveletek alteszteknél jelent meg, mely tesztek azonban ugyanannak a tesztrendszernek a különböző elemei (lásd: 8. táblázat).

A továbbiakban a két tesztrendszer (eDia és DIFER) esetében a matematikai készségek fejlettségének elemzését helyeztük a középpontba. Vizsgálataink tárgya ekkor az elemi számolás, elemi számlálás és elemi műveletvégzés lett, és a két tesztrendszer ezekhez a kognitív részképességekhez kapcsolódó tesztjeinek eredményeit hasonlítottuk össze. Mint a fonémákkal végzett tesztek esetében, itt is csekély, vagy alacsony korrelációt mértünk. Erôsebb összefüggés szintén csak az eDia két altesztje között mutatkozott - az elemi számlálás és az elemi múveletvégzés között (lásd: 9. táblázat).

\section{8. táblázat: Fonémákekal végzett müveletek eredményei (forrás: a Szerzơó)}

\begin{tabular}{l|r|r|r} 
Változó & eDia-fonémaazonositás & eDia-fonémamúveletek & DIFER-beszédhanghallás \\
\hline $\begin{array}{l}\text { eDia olvasás előkészségei }- \\
\text { fonémaazonosítás }\end{array}$ & 1 & $0,586^{*}$ & $0,420^{*}$ \\
\hline $\begin{array}{l}\text { eDia olvasás elókészségei }- \\
\text { fonémamúveletek }\end{array}$ & & 1 & $0,424^{*}$ \\
\hline DIFER - beszédhanghallás & & & 1
\end{tabular}
$*_{p} \leq 0,01$ 
9. táblázat: Elemi matematikai müveletek tesztjének eredményei (forrás: a Szerzó)

\begin{tabular}{l|r|r|r} 
Változó & eDia-elemi számlálás & eDia-elemi műveletvégzés & \multicolumn{2}{|l}{ DIFER-elemi számolás } \\
\hline eDia elemi számlálás & 1 & $0,637^{*}$ & 0,232 \\
\hline eDia elemi múveletvégzés & & 1 & $0,449^{*}$ \\
\hline DIFER - elemi számolás & & & 1
\end{tabular}

$*_{\mathrm{p}} \leq 0,01$

$\mathrm{Az}$ alkalmazott tesztek között négy olyat tudtunk azonosítani, ahol a tanulók vizuális észlelésén alapuló kognitív képességeit tudtuk mérni. A Raven színes progresszív mátrixok olyan intelligenciateszt, ahol a tanulóknak előre megadott mintázatokat és sorozatokat kell felfedezniük. A sikerességet meghatározza, hogy a vizsgált személy milyen minőségben tudja azonosítani a sorok és oszlopok rendezőelvét, és a felfedezett szabályok alapján milyen hatékonysággal tudja kiválasztani a jó megoldást a felkínált lehetőségek közül. A sorok és oszlopok rendezőelvének felfedezése és a szabályok alkalmazásának képessége szintén komoly szerepet kap az eDia rendszer induktív gondol- kodás tesztjében, mégpedig a figurális sorok és a figurális analógiák résztesztekben. Hasonló kognitív folyamatokat mér a Kognitív profil teszt figurateszt mérőeszköze. Mindegyik esetben a tanulók vizuális észlelésén alapuló kognitív képességeit mértük, melyek során a tanulóknak szabályokat kellett felismerniük, és a sorok hiányzó tagjait a szabályok alkalmazásával kellett megtalálniuk. Bár a tesztek színes geometriai formákat alkalmaznak, melyek közül egyet kell a hiányzó helyekre kiválasztani, a teszteredmények között ebben az esetben sem volt kimutatható közepesnél magasabb korreláció (lásd: 10. táblázat).

10. táblázat: Vizuális érzẹ́kelésen alapuló tesżtek eredményei (forrás: a Sžrzö)

\begin{tabular}{|c|c|c|c|c|c|}
\hline & $\begin{array}{l}\text { IQ } \\
\text { (Raven CPM) }\end{array}$ & Figurateszt & $\begin{array}{l}\text { Figurális } \quad \text { sorok } \\
\text { (eDia) }\end{array}$ & $\begin{array}{l}\text { Figurális } \\
\text { (eDia) }\end{array}$ & analogiák \\
\hline IQ (Raven CPM) & 1 & $0,294 * *$ & $0,344^{*}$ & & 0,223 \\
\hline Figurateszt & & 1 & $0,428^{*}$ & & 0,205 \\
\hline Figurális sorok (eDia) & & & 1 & & $0,542^{*}$ \\
\hline Figurális analógiák (eDia) & & & & & 1 \\
\hline
\end{tabular}

${ }^{*} \mathrm{p} \leq 0,05{ }^{* *} \mathrm{p} \leq 0,05$

Nem meglepő módon a DIFER teszt szocialitás pontszáma erősen korrelál a tapasztalati következtetés pontszámával. Tehát a pozitív, inspiráló és támogató szociális háttérrel, így fejlettebb szociális alapkompetenciákkal is rendelkező tanulók rendre jobb teljesítményt értek el azokban a feladatokban, ahol előzetes ismereteikre kellett támaszkodniuk, és ebből a tudásukból további következtetéseket kellett levonniuk. A szocialitás pontszáma a relációszókincs fejlettségével is kimutatható összefüggést jelzett. Ennek értelmében a rendezett szociokulturális háttérrel rendelkezô tanulók szókincse fejlettebb, gondolataikat jobban ki tudják fejezni, valószínúleg a verbális feladatokban eredményesebben lesznek képesek teljesíteni, mint azok a tanulók, aki nem ilyen rendezett szociális körből érkeztek. (Snow és mtsai, 1998; Kende és Illés, 2007; Józsa és Steklács, 2009). A teszteredmények összefüggéseiből válogattunk a 11. táblázatban. 


\section{1. táblázat: Közepesnél erösebb korrelációs kapcsolatok a tesz̨teredményekben (forrás: a Sžerzö)}

\begin{tabular}{l|l} 
Változók & $\mathrm{r}$ \\
\hline Szocialitás (DIFER) - Tapasztalati következtetés (DIFER) & $0,763^{*}$ \\
\hline Induktív gondolkodás - Elemi számolás (DIFER) & $0,705^{*}$ \\
\hline Szocialitás (DIFER) - Relációszókincs (DIFER) & $0,693^{*}$ \\
\hline Elemi számolás (DIFER) - Arab számok (eDia) & $0,657^{*}$ \\
\hline Osztályozás (eDia) - Elemi számolás (DIFER) & $0,623^{*}$ \\
\hline Szocialitás (DIFER) - Tapasztalti összefüggésmegértés (DIFER) & $0,527^{*}$ \\
\hline RQ - Írásmozgás koordináció (DIFER) & $0,521^{*}$ \\
\hline Korai számolási készség (eDia) - Elemi számolás (DIFER) & $0,505^{*}$
\end{tabular}

$*_{\mathrm{p}} \leq 0,01$

\section{Korlátozások}

Tanulmányunkban az iskola elôkészítő szakaszát megelőző diagnosztikus képességazonosítás egy helyi jó gyakorlatát mutattuk be. A bevont minta kislétszámú volt, azonban helyi sajátosságként nem is törekedtünk semmilyen értelemben a reprezentativitásra, csupán intézményünk első osztályos tanulóinak tanulási elóképességeiról kívántunk összetett képet kapni. A tesztek alkalmazása során több meglepő eredményt kaptunk, melyek közül kiemelkedik, hogy nem találtunk lényegi összefüggést az tesztmegoldások minősége és az életkor, valamint az intelligenciahányados között. Számos olyan tesztet alkalmaztunk, melyek előzetes véleményünk szerint hasonló képességterületeket hivatottak mérni (fonémamúveletek vagy elemi számolás), azonban ezen tesztek eredményei nem korreláltak. Ennek okaként határozottan felmerült bennünk, hogy a DIFER tesztet személyes keretek között, társas kapcsolatban vettük fel, míg a többi teszt rögzítésére online környezetben került sor. Törekvésünk volt az is, hogy megtaláljuk azokat a teszteket, melyek adott esetben helyettesíthetik, kiválthatják egymást, így a komplex kép megalkotásához kevesebb tesztalkalomra lenne szükségünk a jövőben. Ez a célunk nem teljesült, így döntés előtt állunk, vagy önállóan tesszük le a voksunk az egyik teszt mellett, vagy más tanulócsoportokban is tovább elemezzük a tesztek közötti összefüggéseket. Lehetőségként felmerül, hogy megtartjuk az eDia rendszer és a DIFER alkalmazását is, ezzel kapva összetettebb képet tanulóinkról.

\section{Konklúziók}

Napjaink modern iskolájával szemben elvárásként jelenik meg az az igény, hogy az oktatás-nevelés minden területén mutasson inkluzív tudatosságot. Ez a befogadáson túl azt is magában hordozza, hogy minden egyes tanuló a saját, egyéni igényeinek megfelelő képzésben és nevelésben részesülhet. Az egyéni sajátosságoknak megfeleló pedagógiai gyakorlat azonban nem képzelhető el a tanulók alapos megismerése nélkül. A tanulói megismerésnek több színtere lehet, a pedagógus megfigyelésétől és értékítéletétôl is erősen függhet a differenciálás megszervezése. Ennél szofisztikáltabb megoldásként áll előttünk, hogy a diagnosztikus megismerés során használjuk fel a pedagógia és a pszichológia tudományainak számunkra hozzáférhető tesztjeit. A tanulmányban bemutatott tesztek többsége - a Raven CPM kivételével - a köznevelés szereplói számára is elérhetôk, felvételük és kiértékelésük intézményi keretek között megoldható. Helyi gyakorlatunk tapasztalatai alapján további komplex tesztrendszerek megismerésére, vagy akár saját mérőeszközök kidolgozására és elemzésére van szükség a kognitív érettség és a személyiségjegyek teljes feltérképezéséhez.

\section{Irodalom}

Báthory, Z. (1992). Tanulók, iskolák - különbségek. Egy differenciális tanitáselmélet vázlata. Tankönyvkiadó, Budapest 
Carroll, J. B. (1993). Human cognitive abilities. A survey of factor-analytic studies. Cambidge University Press, Cambridge.

Csapó, B., Csíkos, Cs., és Molnár, Gy. (szerk. 2015). A matematikai tudás online diagnosztikus értékelésének tartalmi keretei. Oktatáskutató és Fejlesztő Intézet, Budapest

Csapó, B., Steklács, J., és Molnár, Gy. (szerk. 2015). A olvasás-sqüvegértés online diagnosztikus értékelésének tartalmi keretei. Oktatáskutató és Fejlesztő Intézet, Budapest

Csapó, B., és Zsolnai, A. (szerk. 2015). Online diagnosztikus mérések az iskola keqdő sqakaszában. Oktatáskutató és Fejlesztő Intézet, Budapest

Gardner, H. (1999). Intelligence Reframed. Basic Books. New York, Amerikai Egyesült Államok

Goodenough, F. (1926). Measurement of intelligence by drawings. New York: World Book Co

Gyarmathy, É. (2009). Kognitív Profil Teszt In Iskolakultura 3-4., Budapest, 60-73.

Józsa, K. (2004). Az első osztályos tanulók elemi alapkészségeinek fejlettsége - Egy longitudinális kutatás első mérési pontja. In Iskolakultúra 14. 11. sz: Budapest, 3-16.

Lányiné Engelmayer Á., Nagy É., Nagyné Réz I., Ringhofer J. és Szegedi M. (1996). Az intelligencia mérése gyermekeknél. In Kun, M. és Szegedi, M. (szerk.). Az intelligencia mérése, Akadémiai Kiadó, Budapest, 227-305.

Mező, F., és Mező K. (2007): Tanulás: diagnosztika és fejlesztés az IPOO-modell alapján, Kocka Kör Tehetséggondozó Kulturális Egyesület, Debrecen

Mező, F. (2016). Az IQ-paradoxon. Különleges Bánásmód, II. évf., 2016/1., 43-60.

Mező, F., Mező, K. (2017). Az originalitás mérő és becslő módszereinek konkurens validitása. Különleges Bánásmód, III. évf., 2017/3., 27-38.
Mérei, F. és Szakács, F. (1995): A Raven-féle vizsgálati elv és teszt. In Torda Ágnes (szerk.) Psz̧ichodiagnosz̨tika I. Tanulmányok a gyógypedagógiai lélektan pszichodiagnosztikai eljárásainak köréböl. Tankönyvkiadó Vállalat, Budapest, 52.

Molnár, Gy. (2015). A képességmérés dilemmái: A diagnosztikus mérések (eDia) szerepe és helye a magyar közoktatásban. Géniusz Mühely 15., Magyar Tehetségsegítő Szervezetek Szövetsége., Budapest 1628.

Molnár, Gy., és Korom, E. (szerk. 2013). Az iskolai sikerességet befolyásoló kognitiv és affektiv tényezőo értékelése, Nemzedékek Tudása Tankönyvkiadó Zrt, Budapest

Nagy, J. (2000). A XXI. száąad és nevelés. Osiris Kiadó, Budapest.

Nagy, J., Józsa, K., Vidákovics, T. és Fazekasné Fenyvesi, M. (2004). DIFER Programosomag. Diagnosztikus fejlódésvizsgáló és kritériumorientált fejlesztô" rendszer 4-8 évesek számára, Mozaik Kiadó, Szeged

Raven, J., Raven, J.C., és Court, J.H. (2003). Manual for Raven's Progressive Matrices and Vocabulary Scales. Section 1: General Overview. San Antonio, TX: Harcourt Assessment.

Smythe, I. (2002). Cognitive factors underlying reading and spelling difficulties: a cross linguistic study. Thesis submitted for the degree of Doctor of Philosophy, Department of Psychology, School of Human Sciences, University of Surrey, Guildford.

Torda, Á. (1988): Az emberalak ábrázolásának minősítése Goodenough-féle eljárással. In: $A$ differenciált beiskolázás nébány mérôeszköze (szerk. Gerebenné Várbíró, K. - Vidákovich, T.) Akadémiai Kiadó, Budapest, 73-88.

Torda, Á. és Darvas, Á. (2001). Példatár az emberalakábrázolás és a vizou-motoros koordináció diagnosztikus értékeléséhez, ELTE BGGYFK, Budapest 